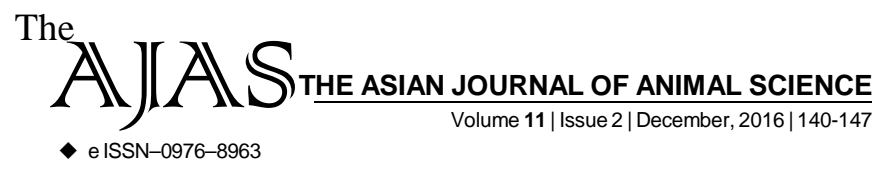

DOI : 10.15740/HAS/TAJAS/11.2/140-147

Visit us | www.researchjournal.co.in

RESEARCH ARTICLE........

\title{
Study of HACCP and microbial quality of seafood during processing in plants around Kolkata
}

\author{
C. DUTTA, S. NATH, S. CHOWDHURY, A.K. PANIGRAHI AND C. SENGUPTA
}

\begin{abstract}
Food quality has become a considerable issue in food sector over the past decade. The food safety concepts are gaining attention not only in developed countries but also in developing countries like India. Finfish and shellfish are some of the highly perishable commodities, so, systematic approach is required to maintain quality during processing. There is a worldwide trend towards food safety and quality in order to prevent food borne illness. For ensuring food safety there are several quality control systems, out of which the Hazard Analysis and Critical Control Point (HACCP) is the most acceptable. In the present study, a survey was made to put an idea of implementation Quality Assurance and HACCP system in seafood plants in West Bengal. The bacteriological loads in all these plants were studied and found acceptable as per ICMSF (1988) guidelines. Further, an attempt was made to identify Critical Control Point (CCP) during receiving end of raw material at seafood processing plants. Thrust was given to adopt Total Quality Management practices during inspection of processing plants.
\end{abstract}

\section{S. CHOWDHURY}

Department of Fish Processing

Technology, Faculty of Fishery

Science, West Bengal University

of Animal and Fishery Sciences,

KOLKATA (W.B.) INDIA

Email: supratimchowdhury@

yahoo.com

See end of the article for

Coopted authors'
KEY WORDS....... HACCP, CCP, Quality assurance, Bacterial load, Seafood

HOW TO CITE THIS ARTICLE - Dutta, C., Nath, S., Chowdhury, S., Panigrahi, A.K. and Sengupta, C. (2016). Study of HACCP and microbial quality of seafood during processing in plants around Kolkata. Asian J. Animal Sci., 11(2): 140-147. DOI : 10.15740/HAS/TAJAS/11.2/140-147.

ARTICLE CHRONICLE - Received : 02.10.2016; Revised : 03.11.2016; Accepted : 18.11.2016 